\title{
Revista Ciencia Multidisciplinaria CUNORI
}

http://revistacunori.com

DOI: https://doi.org/10.36314/cunori.v2i1.72

ISSN: 2617- 474X (impresa) / 2617- 4758 (en línea)

\section{P15 -Presentación del libro Tentativas de Carlo Ginzburg}

\author{
Presentation of the book Tentatives of Carlo Ginzburg \\ Oscar Guillermo Peláez Almengor*, María Teresa Mosquera \\ Tulane University, New Orleans, Louisiana \\ Estados Unidos de América* \\ ${ }^{2}$ Instituto de Estudios Interétnicos-USAC
}

*Autor para correspondencia.

Correo electrónico: teresa_mosquera@yahoo.com.mx

Resumen

$\mathrm{E}$ 1 libro presenta una serie de trabajos sobre temas diversos, que ilumina el desarrollo de las ciencias humanas a nivel planetario.

El primer ensayo es; el palomar ha abierto los ojos: conspiración popular italiana del siglo XVII, se centra en los intermediarios o mediadores culturales. El segundo ensayo: el hombre y el cómo: intercambio desigual y mercado historiográfico. El tercer ensayo: Huellas. Raíces de un paradigma indiciario, en este se presentan ejemplos de la aplicación del paradigma indiciario. El cuarto ensayo: intervención sobre el paradigma indiciario. El quinto ensayo: Datación absoluta y datación relativa: sobre el método Longhi. El sexto ensayo: De todos los regalos que le traigo Al kaisare... interpretar la película escribir la historia, en el introduce como fuente de investigación el cine. El séptimo ensayo: Pruebas y posibilidades. Comentario al margen del libro "El regreso de Martín Guerre" son fuentes judiciales para estudiar el mundo de los campesinos franceses del siglo XVI. El octavo ensayo: Acerca de la historia local y la microhistoria. El noveno ensayo: Saqueos rituales. Premisas para una investigación en curso aborda el problema de los saqueos a viviendas de personas de clases altas y su continuidad hasta nuestros días. El décimo ensayo: El inquisidor como antropólogo se centra en los inquisidores y en los juicios o procesos por herejías. El último ensayo es: conversar con Orión.

Palabras clave: libro, tentativas, ciencias humanas

\begin{abstract}
$I^{1}$ The book presents a series of works on different topics that illuminate the development of the human sciences at the planetary level. The first trial is; the loft has opened its eyes: Italian popular conspiracy of the seventeenth century, focuses on intermediaries or cultural mediators. The second essay: man and the how: unequal exchange and historiographical market. The third trial: Footprints. Roots of an indexical paradigm, in this examples are presented of the application of the indicative paradigm. The fourth essay: intervention on the indexical paradigm. The fifth essay: Absolute dating and relative dating: on the Longhi method. The sixth essay: Of all the gifts I bring to Al kaisare ... to interpret the film to write history, in which he introduces cinema as a source of research. The seventh essay: Tests and possibilities. Comment on the margin of the book "The return of Martin Guerre" are judicial sources to study the world of French peasants of the sixteenth century. The eighth essay: About local history and microhistory. The ninth essay: Ritual Sackings. Premises for an ongoing investigation addresses the problem of looting of high-class housing and its continuity to this day. The tenth essay: The inquisitor as an anthropologist focuses on the inquisitors and the judgments or trials for heresies. The last essay is: converse with Orion.
\end{abstract}

Keywords: book, attempts, human sciences 


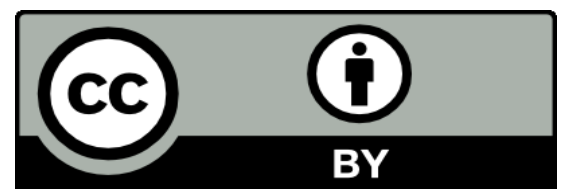

Este texto está protegido por una licencia CreativeCommons 4.0.

Usted es libre para compartir, copiar y redistribuir el material en cualquier medio o formato y adaptar el documento, remezclar, transformar y crear a partir del material para cualquier propósito, incluso comercialmente, siempre que cumpla la condición de atribución: usted debe reconocer el crédito de una obra de manera adecuada, proporcionar un enlace a la licencia, e indicar si se han realizado cambios. Puede hacerlo en cualquier forma razonable, pero no de forma tal que sugiera que tiene el apoyo del licenciante o lo recibe por el uso que hace. 